\section{BMJ Paediatrics Open}

\title{
Economic sanctions on countries are indiscriminate weapons and should be banned
}

\author{
Imti Choonara (D) , ${ }^{1}$ Maurizio Bonati (D) , ${ }^{2}$ Paul Jonas (D) ${ }^{3}$
}

To cite: Choonara I, Bonati M, Jonas P. Economic sanctions on countries are indiscriminate weapons and should be banned. BMJ Paediatrics Open 2021;5:e001350. doi:10.1136/ bmjpo-2021-001350

Received 17 November 2021 Accepted 2 December 2021

Check for updates

(C) Author(s) (or their employer(s)) 2021. Re-use permitted under CC BY-NC. No commercial re-use. See rights and permissions. Published by BMJ.

${ }^{1}$ Department of Child Health, University of Nottingham School of Medicine, Derby, UK ${ }^{2}$ Department of Public Health, Laboratory for Mother and Child Health, Mario Negri Institute for Pharmacological Research, Milano, Italy

${ }^{3}$ Department of Public Health and Primary Care, Leiden University Medical Center, Leiden, The Netherlands

Correspondence to Emeritus Professor Imti Choonara; Imti.Choonara@ nottingham.ac.uk
Economic sanctions are usually applied by governments or the United Nations Security Council (UNSC) to individuals, companies or countries. ${ }^{1}$ Such sanctions may be appropriate when applied to individuals or companies. Economic sanctions on countries, however, cannot be justified in any circumstances. There is overwhelming evidence of the adverse effects of economic sanctions on both the health and nutrition of the civilian population. ${ }^{2}$ It is usually the most disadvantaged sections of society, who experience the greatest harm.

Economic sanctions are the modern equivalent of a siege. Sieges have usually been applied to cities, for example, Sarajevo and Aleppo, whereas economic sanctions are applied to countries. The effects of both sieges and sanctions are similar: depriving civilians of access to basic services as well as food and medicines. The UNSC has unanimously adopted resolutions demanding the lifting of sieges ${ }^{3}$ and stating that the use of such sieges against civilian populations in Syria were illegal under international humanitarian law. ${ }^{4}$ The devastating impact of sieges on health, medical services and access to food and other basic services have been highlighted by researchers. ${ }^{56}$ It is unfortunate that the global superpowers that dominate the UNSC recognise the indiscriminate impact of sieges on civilians, but not economic sanctions.

Economists have studied the effect of economic sanctions on 98 countries over a period of 35 years. ${ }^{2}$ Their results suggest that UN sanctions reduce life expectancy by 1.2-1.4 years and that sanctions by the USA reduce life expectancy by $0.4-0.5$ years. ${ }^{2}$ Their work suggests that an increase in child mortality and deaths due to cholera alongside decreased spending on public health were the main reasons for the decreased life expectancy. ${ }^{2}$ They also identified that women were more severely affected by sanctions. They have previously demonstrated that economic sanctions by the USA increase poverty among the poorest people. ${ }^{7}$ Economic sanctions are usually applied by rich countries on poorer countries and this is likely to result in increased inequalities.

The devastating effect of economic sanctions by the UNSC on child health have been extensively reported for Iraq. Infant mortality increased from 47 to 108 per 1000 live births and under 5 mortality increased from 56 to 131 per 1000 live births, following the imposition of economic sanctions in $1990 .{ }^{8}$ One group have estimated that 567000 children died as a result of the economic sanctions. ${ }^{9}$ Nutritional problems, an increase in infectious diseases and an increase in low birth weight were all reported. ${ }^{10}$

Iran has experienced economic sanctions by both the UNSC and the USA. The UNSC lifted their economic sanctions in January 2016 and the USA reimposed their economic sanctions in November 2018. The availability of medicines in Iran was significantly reduced during the UNSC sanctions. ${ }^{11}$ Concern was raised that publishers of medical journals were refusing to consider papers from Iran in case they were in breach of US sanctions. ${ }^{12} \mathrm{~A}$ systematic review identified 55 papers documenting the adverse health effects of sanction on the population of Iran. ${ }^{13}$

The impact of economic sanctions on the most disadvantaged is highlighted by a review of the impact of economic sanctions on 71 countries from 1990 to 2012 and HIV in children. ${ }^{14}$ AIDS-related death rates increased by approximately $1 \%$ in children with HIV and new infection rates increased by $2.5 \% .^{14}$

The USA has imposed economic sanctions on more countries than any other country. ${ }^{7}$ One country in particular, Cuba, has experienced economic sanctions by the USA for 60 years. The sanctions are comprehensive (including food, medicines and medical 
equipment) and have extraterritorial components which effectively make it difficult for other countries to trade with Cuba. These extraterritorial components have been declared illegal by the British Government. In January 2019, the Conservative Minister for Europe and the Americas stated in the House of Commons 'that under the UK Protection of Trading Interests Act 1980, it is illegal for UK companies to comply with extraterritorial legislation such as the US embargo'. ${ }^{15}$ The European Union has also stated that the extraterritorial aspects of the US sanctions are illegal. ${ }^{16}$ Each year the UN General Assembly votes overwhelmingly for the sanctions to be lifted.

A comprehensive report by Oxfam details the impact of the US sanctions on Cuba. ${ }^{17}$ It highlights difficulties in obtaining basic medical supplies such as syringes, masks, ventilators, medicines as well as the raw materials needed to produce vaccines, medicines and sanitary hygiene products. ${ }^{17}$ Shortages of food and other basic products affect the most vulnerable in Cuba and the tightening of the sanctions has increased inequalities in Cuba. ${ }^{17}$ Even collaboration between Cuban and American scientists has been blocked by the US sanctions. ${ }^{18}$ President Obama and others have recognised that the sanctions against Cuba were ineffective. ${ }^{19} 20$ Unfortunately, both President Trump and Biden have expanded the sanctions. American health professionals have called for the lifting of sanctions on Cuba. ${ }^{21}$ The impact of the sanctions has been exacerbated by the COVID-19 pandemic. ${ }^{22} 23$

The legality of economic sanctions on countries has been questioned. ${ }^{2425}$ The use of indiscriminate weapons on a civilian population is recognised as unlawful. The Fourth Geneva Convention of 1949 was an attempt to protect civilians from harm during wars. ${ }^{26}$ Subsequent protocols adopted in 1977 tried to ensure greater protection for civilians. ${ }^{26}$ As health professionals, we are concerned about the indiscriminate effect of economic sanctions on countries on the human rights and health of civilians.

Economic sanctions on countries are inconsistent with the UN Convention on the Rights of Children and in particular articles 24, 26 and 28 which concern the rights of children to access healthcare, social welfare and education. ${ }^{27}$ Every nation has ratified the Convention, with the exception of the USA. We call on paediatric professional organisations of member states of the UN Security Council to lobby their governments to recognise that economic sanctions cause more harm than good to children in poor countries. The American Academy of Pediatrics and the Royal College of Paediatrics and Child Health (UK) should take the lead on this issue and issue statements calling on their governments and the UN to stop using economic sanctions on countries.

We call on the International Committee of the Red Cross to work with health professionals and their organisations, and other relevant parties to amend the Geneva Convention by adopting a new protocol recognising that: 1. Extraterritorial economic sanctions are illegal under international law and should be banned immediately.
2. Economic sanctions on a country are inhumane and should be banned as soon as possible.

Correction notice This article has been corrected since it was first published. The ORCID id for the author Paul Jonas has been added.

Twitter Maurizio Bonati @mumchild_irfmn

Contributors All authors contributed to the article.

Funding The authors have not declared a specific grant for this research from any funding agency in the public, commercial or not-for-profit sectors.

Competing interests IC is Editor in Chief for BMJPO. MB is on the Editorial Advisory Board for BMJPO.

Patient and public involvement Patients and/or the public were not involved in the design, or conduct, or reporting, or dissemination plans of this research.

Patient consent for publication Not applicable.

Ethics approval This study does not involve human participants.

Provenance and peer review Commissioned; externally peer reviewed.

Open access This is an open access article distributed in accordance with the Creative Commons Attribution Non Commercial (CC BY-NC 4.0) license, which permits others to distribute, remix, adapt, build upon this work non-commercially, and license their derivative works on different terms, provided the original work is properly cited, appropriate credit is given, any changes made indicated, and the use is non-commercial. See: http://creativecommons.org/licenses/by-nc/4.0/.

\section{ORCID iDs}

Imti Choonara http://orcid.org/0000-0002-3069-6323

Maurizio Bonati http://orcid.org/0000-0003-3997-3726

Paul Jonas http://orcid.org/0000-0001-5794-350X

\section{REFERENCES}

1 Choonara I. Economic sanctions and child health. Med Confl Surviv 2013;29:93-8.

2 Gutmann J, Neuenkirch M, Neumeier F. Sanctioned to death? The impact of economic sanctions on life expectancy and its gender gap. J Dev Stud 2021;57:139-62.

3 United Nations. Security Council Unanimously Adopts Resolution 2139 (2013) to Ease Aid Delivery to Syrians, Provide Relief from 'Chilling Darkness'. Available: https://www.un.org/press/en/2014/ sc11292.doc.htm [Accessed 17 Nov 2021].

4 United Nations Security Council. Resolution 2401. The situation in the middle East, 2018. Available: http://unscr.com/en/resolutions/ 2401 [Accessed 17 Nov 2021].

5 Nijs M. Humanizing siege warfare: applying the principle of proportionality to sieges. International Review of the Red Cross 2021.

6 Pretto EA, Begovic M, Begovic M. Emergency medical services during the siege of Sarajevo, Bosnia and Herzegovina: a preliminary report. Prehosp Disaster Med 1994;9:S39-45.

7 Neuenkirch M, Neumeier F. The impact of US sanctions on poverty. $J$ Dev Econ 2016;121:110-9.

8 Ali MM, Shah IH. Sanctions and childhood mortality in Iraq. Lancet 2000;355:1851-7.

9 Zaidi S, Smith Fawzi M. Health of Baghdad's children. The Lancet 1995;346:1485

10 Al-Nouri L, Al-Rahim Q. The effect of sanctions on children of Iraq. Arch Dis Child 2003;88:92

11 Kheirandish M, Varahrami V, Kebriaeezade A, et al. Impact of economic sanctions on access to noncommunicable diseases medicines in the Islamic Republic of Iran. East Mediterr Health J 2018;24:42-51.

12 Arie S. Unintended consequences of sanctions against Iran. BMJ 2013;347:f4650.

13 Kokabisaghi F. Assessment of the effects of economic sanctions on Iranians' right to health by using human rights impact assessment tool: a systematic review. Int J Health Policy Manag 2018;7:374-93.

$14 \mathrm{Kim}$ Y. Economic sanctions and child HIV. Int J Health Plann Manage 2019;34:693-700.

15 Duncan A. Hansard. Available: https://hansard.parliament.uk/ Commons/2019-01-22/debates/BD354790-EEFF-4939-95DFDAE62201765/USTradeRestrictionsOnCuba?highlight=cuba\# contribution-B174BF17-BF0E-49A8-88E5-154BCC232CF3 [Accessed 31 Oct 2021]. 
16 European Union. Statement by the high Representative/VicePresident Josep Borrell on US sanctions. Available: https://eeas. europa.eu/headquarters/headquarters-homepage_en/83105/ Statement\%20by\%20the\%20High\%20Representative/VicePresident\%20Josep\%20Borrell\%20on\%20US\%20sanctions [Accessed 17 Nov 2021].

17 Oxfam. Right to live without a blockade, 2021. Available: https:// www.oxfamamerica.org/explore/research-publications/right-to-livewithout-a-blockade/ [Accessed 07 Nov 2021]

18 Lenzer J. US researchers blocked from testing Cuban drug. BMJ 2016;352:i1642.

19 Sabatini C. US-Cuba sanctions: are they working yet? Chatham house, 2020. Available: https://www.chathamhouse.org/2020/08/uscuba-sanctions-are-they-working-yet [Accessed 07 Nov 2021]

20 WTO. "Can Economic Sanctions be Effective?", WTO Working Papers. Geneva: WTO, 2018.

21 Drain PK. Implications of Repealing the Cuban embargo for US medicine and public health. Am J Public Health 2015;105:2210-1.
22 The War on Cuba Part 5. Available: https://www.youtube.com/ watch? $v=$ WavOrU-g2E4 [Accessed 17 Nov 2021]

23 Sanctions in a pandemic. Part 1. Available: https://www.youtube. com/watch? $v=x G 5 n M B I 5 R Z g$ [Accessed 17 Nov 2021].

24 Morin K, Miles SH. The health effects of economic sanctions and embargoes: the role of health professionals. ethics and human rights Committee. Ann Intern Med 2000;132:158-61.

25 Mohamad R. Unilateral sanctions in International Law: a quest for legality. In: Marossi A, Bassett M, eds. Economic sanctions under international law. The Hague: T.M.C. Asser Press, 2015.

26 International Committee of the red cross. Available: https://www. icrc.org/en/doc/war-and-law/treaties-customary-law/genevaconventions/overview-geneva-conventions.htm [Accessed 07 Nov 2021].

27 United Nations. Convention on the rights of the child. Available: https://www.unicef.org.uk/wp-content/uploads/2010/05/UNCRC_ united_nations_convention_on_the_rights_of_the_child.pdf [Accessed 24 Nov 2021]. 